\title{
2 \\ NEW HORIZONS FOR A BRITISH MINING HOUSE
}

The Consolidated Gold Fields of South Africa undertook an expansive international investment program in the early part of the twentieth century. New Consolidated Gold Fields was formed in August 1919, with a capital of GB£4.5 million, equal to the capital of The Consolidated Gold Fields of South Africa. This was now a dedicated company for international expansion outside the company's origins and primary source of gold production in South Africa. It supplemented the activities of The Gold Fields American Development Company, formed in 1911 to manage the American interests of the group and that had also pursued investments in gold mines in West Africa, as well as establishing a portfolio of investments in other countries.

Not least of the countries assessed as attractive by New Consolidated Gold Fields was Australia. Here a combination of factors served to assist the company establish business interests, mainly in Western Australian gold mining and, in so doing, contribute to the regeneration of gold mining activities in this state from the late 1920s.

Gold Fields' initial investments in Australia were aided by two sets of factors. First, Australian mining companies continued to establish listings on the London Stock Exchange as a source of deeper financing than could be obtained in Australia. Gold Fields had relationships with all of the main stockbrokers in the City of London that had a knowledge of mining investment opportunities in Australia. The most noteworthy of these were Lionel Robinson \& Clark, with its association with WS (William Sydney) Robinson. Robinson was a founding member of the Collins House Group 
of companies, an informal confederation of Australian businessmen with investments in mining, processing and allied areas. Another London stockbroker was Govett, Sons and Co. and its principal, Francis Algernon Govett. ${ }^{1}$ The London broking firms and their associates were influential in introducing Gold Fields to a range of potential mining investments in Australia. Yet another key connection for Gold Fields was Claude Albo de Bernales, a Western Australian entrepreneur active in promoting mining interests in London. He was instrumental in introducing Gold Fields to its first major gold investment in Western Australia, at Wiluna.

The second factor was the existence of individuals with engineering and mining backgrounds who had first-hand experience of mining operations, typically in the Western Australian goldfields. In this regard, two individuals, a father and son, were influential in charting the course of Gold Fields' activities in Australia: John A Agnew and Rudolph (Dolph) J Agnew. John Agnew became a director of Consolidated Gold Fields of South Africa and New Consolidated Gold Fields, serving as their chairman, while Dolph served in operational roles at a number of Western Australian gold mines and on the London board of directors of several group companies.

Gold Fields pursued investments in the 1920s and early 1930s in various Western Australian gold mining ventures, a lead and zinc mine in New South Wales, and two gold mining ventures in New Guinea. In 1930 the company also joined a group of companies established at the initiative of WS Robinson to evaluate mining opportunities throughout Australia. Three companies were established: Gold Mines of Australia, Gold Exploration and Finance Company of Australia Limited, and Western Mining Corporation. Gold Fields held major shareholdings in all three and played an influential role in their early development. For Gold Fields, this provided access to multiple mining opportunities, experienced and well-connected mining men in Australia and a dedicated financing arm. While the association offered much, it ultimately did not provide Gold Fields with the basis to establish the broad business base it sought in Australia. Gold Fields was reluctant to continue to be involved in companies in which South African competitors also had shareholdings,

1 Kelly, 'FA Govett, Chairman and Managing Director'; Appleyard and Schedvin, Australian Financiers: Biographical Essays, pp. 237-239. The City of London was a major source of funding for Australian mining projects from 1895 to 1899 , as well as a source of mining engineering skills, including from the firm Bewick, Moreing \& Co (Harvey and Press, 'The City and International Mining', pp. 105 and 114). 
or to support the evaluation and pursuit of joint mining ventures in Western Australia - a state where it had a presence and where it believed its interests were better served if pursued alone. ${ }^{2}$

Gold Fields established its own investment vehicle for its Australian ventures. In 1932, Gold Fields Australian Development Company was listed on the London Stock Exchange as a holding company for its investments and as a platform for identifying further opportunities in both gold and base metals. A number of investments were made, most notably an extension of the Wiluna gold mining operations, through an involvement in the Moonlight Wiluna mine and associated deposits.

The opportunities evaluated in Australia over a 30-year period from the mid-1920s were extensive and indicated a commitment to establishing a broad-ranging business presence in Australia. The success of the investments varied. Involvement in the Lake View and Star gold mine in the Golden Mile of Kalgoorlie was fabulously successful and the initial investment in the Wiluna gold mine in east Coolgardie provided the company with a shorter, although lucrative source of dividends. Holdings in the Yellowdine and Mount Ida gold mines in Western Australia were profitable, although for shorter periods. The Lake George mine at Captains Flat in New South Wales had a period of profitability in the 1950s but by the second half of that decade it was nearing the end of its economic life. Investments in New Guinea gold mining had mixed outcomes. A range of other investments, including extensions to the original Wiluna deposit, were less successful and losses accumulated. Interests in gold mining in Victoria and the evaluation of an extension of mineralisation on tenements near Mount Isa Mines in Queensland were of marginal value.

As such, there proved relatively little to provide the basis for the group's longer-term involvement in Australia. With the decline of its gold mining interests and limited success in identifying replacement investment opportunities, New Consolidated Gold Fields (Australasia) was established in 1956 and capitalised with A£1 million to undertake exploration and project development activities. This was to little avail. It was not until an international expansion program in the late 1950s, overseen by Sir George Steven Harvie-Watt, the chief executive and deputy

2 Gold Fields Ltd, 'Company Profile, Information, Business Description, History, Background Information on Gold Fields Ltd', www.referenceforbusiness.com/history2/74/Gold-Fields-Ltd.html. 
chairman of Consolidated Gold Fields of South Africa, that a wider spread of investments in Australia was orchestrated. What followed was the establishment and growth of Gold Fields' presence in Australia in three main phases.

In the period 1960 to 1966 an ambitious and largely successful program of investments occurred under Consolidated Gold Fields (Australia) (CGFA), a wholly owned subsidiary of the British parent.

CGFA established a presence in iron ore, mineral sands, coal, copper, lead, zinc and tin. Its investments spread to minerals processing, manufacturing and agricultural interests, as well as property development. In doing so, CGFA gained ownership of companies that in aggregate were the largest mineral sands producers globally. In securing iron ore tenements in Western Australia, it participated in the first development of iron ore deposits in the Pilbara. It conducted an expansive Australian and international exploration program. The company was also an acquirer of other companies.

Gold Fields' evolution in Australia — the 1960 establishment of a wholly owned subsidiary, the 1966 listing on the Australian stock exchanges and the 1981 'naturalisation' process to become a majority Australian-owned company-promised a great deal. In the late 1980s, despite prior missteps and portfolio challenges, the company's ambitions remained as expansive as they were 30 years earlier. The goal was to establish itself within the top four resource companies in Australia by the late 1990s. However, the challenge of maturing ore bodies, investments in mines that struggled financially under low prices, a lack of material exploration success and the takeover of its parent company in 1989 led to truncation and an ultimate inability to fulfil these ambitions.

In an ironic twist of fate, in the late 1980s Consolidated Gold Fields in London was subject to a long-drawn-out, acrimonious but ultimately unsuccessful takeover attempt by Minorco, a company owned by arch rival Anglo American and its subsidiary, De Beers Mining. While successful in fending off this attempt, Consolidated Gold Fields succumbed to a follow-up takeover offer by renowned corporate raider and asset stripper Hanson Plc. This occurred in 1989 and with it the era of this major British 
mining-finance house, with its array of international interests, came to an end. The Australian offshoot, Renison Goldfields Consolidated (RGC), existed until 1998, with Hanson its major shareholder. ${ }^{3}$

Repeated attempts to find a buyer or buyers for the Hanson stake were unsuccessful. RGC was not able to reassert its independence as a diversified Australian minerals company. After a period of challenging market conditions and management change at the highest echelons of the company, the desire and opportunity by Hanson to exit its long-held and unsatisfactory shareholding became manifest. In 1998 Hanson was approached by the chief executive officer of the Western Australian-based mineral sands company, Westralian Sands. A merger took place between the smaller Westralian Sands and RGC. There was little in the new entity that reflected the asset base-with the exception of mineral sands-or business approach and cultural attributes of the former Gold Fields presence in Australia.

As with other notable companies of the pre- and post-World War II Australian mining landscape, RGC was folded into another company and its heritage as a separate listed company, in this case with connections extending back to the late nineteenth century, came to an end.

The ambitions of CGFA and RGC were expansive. Much was achieved, although periods of poor financial performance punctuated the 38-year history of the companies in Australia. The company contributed much to the Australian minerals sector. However, it fell short of its potential.

3 Renison Goldfields Consolidated, established in 1981, was majority Australian owned. It incorporated the name of what was viewed as its principal and highest-quality asset, Renison, which operated a tin mine in Tasmania. The reference to Gold Fields was retained, although with the adaptation of the original and longstanding use of the two words by their amalgamation into one. In 1998 the company name was shortened to RGC Limited. 
This text is taken from Consolidated Gold Fields in Australia: The Rise and Decline of a British Mining House, 1926-1998, by Robert Porter, published 2020 by ANU Press, The Australian National University,

Canberra, Australia.

doi.org/10.22459/CGFA.2020.02 